\title{
PENGETAHUAN DAN SIKAP PEMAKAIAN KONTRASEPSI PADA REMAJA DI UNIVERSITAS NEGERI MEDAN
}

\author{
Melinda Akmal, Rayhan Utami, Irda Afriza Rao, Mufdi Al Husri, Cintya N. Tambunan \\ Jurusan Pendidikan Geografi, Fakultas IImu Sosial \\ Universitas Negeri Medan \\ Jl. Willem Iskandar Ps V Medan Estate, Medan, 20221, Indonesia \\ Email: rayhanutami@mhs.unimed.ac.id
}

\begin{abstract}
Abstrak
Penelitian ini bertujuan untuk mengetahui bagaimana pengetahuan dan sikap mahasiswa terhadap alat konstrasepsi. Pengumpulan data menggunakan angket dengan menggunakan google formulir. Populasi seluruh mahasiswa Universitas Negeri Medan, dan sampel penelitian ini 70 orang. Adapun varibel bebas pengetahuan konstrasepsi pada remaja dan varibel terikat adalah sikap pemakaian konstrasepsi pada remaja. Hasil penelitian menunjukkan bahwa 90\% responden mengetahui bahwa alat kontrasepsi dapat mencegah kehamilan. Sedangkan sebanyak $50 \%$ responden tidak mengetahui cara memakai berbagai alat kontrasepsi. Sebanyak 64,2\% responden mengetahui bahwa alat kontrasepsi dapat mencegah penyakit menular. Hasil penelitian mengenai sikap mahasiswa tentang pemakaian kontrasepsi menunjukkan sikap yang negative terutama mengenai perilaku melakukan hubungan seks dengan menggunakan alat kontrasepsi agar tidak hamil
\end{abstract}

Kata kunci: pengetahuan, sikap, konstrasepsi

\begin{abstract}
This study aims to find out how students knowledge and attitudes towards contraception devices. Data collection uses questionnaires using Google forms. The population of all state university students, and the sample of this study were 70 people. The free variables of contraception knowledge in adolescents and dependent variables are the attitudes of contraception use in adolescents. The results showed that $90 \%$ of respondents knew that contraception could prevent pregnancy. While as many as 50\% of respondents did not know how to use various contraception. As many as $64.2 \%$ of respondents know that contraception can prevent infectious diseases. The results of the study on student attitudes about contraceptive use showed a negative attitude, especially regarding sexual intercourse behavior using contraception so as not to become pregnant.
\end{abstract}

Keywords: knowledge, attitudes, contraception

\section{PENDAHULUAN}

Pengetahuan merupakan informasi atau maklumat yang diketahui atau disadari oleh seseorang. Dalam pengertian lain, pengetahuan adalah berbagai gejala yang ditemui dan diperoleh manusia melalui pengamatan akal (Muthiah dan Kadarisman, 2014). Pengetahuan muncul ketika seseorang menggunakan akal budinya untuk mengenali benda atau kejadian tertentu yang belum pernah dilihat atau dirasakan sebelumnya. Misalnya ketika seseorang mencicipi masakan yang baru dikenalnya, ia akan mendapatkan pengetahuan tentang bentuk, rasa, dan aroma masakan tersebut.

Pengetahuan adalah informasi yang telah dikombinasikan dengan pemahaman dan potensi untuk menindaki; yang lantas melekat di benak seseorang. Pada umumnya, pengetahuan memiliki kemampuan prediktif terhadap sesuatu sebagai hasil pengenalan atas suatu pola. Manakala informasi dan data sekadar berkemampuan untuk menginformasikan atau bahkan menimbulkan kebingungan, maka pengetahuan berkemampuan untuk mengarahkan tindakan. Ini lah yang disebut potensi untuk menindaki.

Menurut Aiken dalam Rahmadani (2009:11), "sikap sebagai predisposisi atau kecendrungan yang dipelajari dari seorang individu untuk merespon secara positif atau negative dengan intensitas yang moderat atau memadai terhadap objek, situasi, konsep atau orang lain. Sedang sikap sendiri mengandung tiga komponen yaitu : kognisi, 
emosi dan perilaku serta bisa konsisten dan bisa juga tidak (Suharyat, 2009). Tergantung permasalahan apa yang mereka hadapi. Kraus menemukan beberapa faktor yang memprediksi konsistensi sikap dan perilaku seseorang yaitu: stabil sepanjang waktu, dilakukan dengan keyakinan yang tinggi. konsisten dengan reaksi emosi seseorang ke arah perilaku, terbentuk karena pengalaman langsung, mudah diingat.

Kontrasepsi merupakan suatu cara atau metode yang bertujuan untuk mencegah pembuahan sehingga tidak terjadi kehamilan. Negara berkembang seperti Indonesia yang memiliki jumlah penduduk besar mendukung program kontraspesi untuk mengendalikan pertumbuhan jumlah penduduk dan untuk meningkatkan kesejahteraaan keluarga (Aryanti, 2014). Dalam hal ini pemerintah Indonesia menyelenggarakan program Keluarga Berencana atau KB melalui pengaturan kelahiran.

Menurut psikologi, remaja adalah suatu periode transisi dari masa awal anak anak hingga masa awal dewasa, yang dimasuki pada usia kira kira 10 hingga 12 tahun dan berakhir pada usia 18 tahun hingga 22 tahun. Masa remaja bermula pada perubahan fisik yang cepat, pertambahan berat dan tinggi badan yang dramatis, perubahan bentuk tubuh, dan perkembangan karakteristik seksual seperti pembesaran buah dada, perkembangan pinggang dan kumis, dan dalamnya suara. Pada perkembangan ini, pencapaian kemandirian dan identitas sangat menonjol (pemikiran semakin logis, abstrak, dan idealistis) dan semakin banyak menghabiskan waktu di luar keluarga (Lestari, 2013).

Hasil-hasil penelitian terdahulu menunjukkan banyaknya remaja putri belum menikah telah aktif seksual dan berakhir pada masalah kesehatan reproduksi yang membahayakan kesehatan dan jiwa remaja khususnya remaja putri belum menikah. Padahal, menurut kesepakatan dalam Konferensi Internasional Kependudukan dan Pembangunan di Kairo tahun 1994, remaja mempunyai hak untuk kebebasan berpikir dan membuat keputusan tentang kesehatan reproduksinya. Hal itu berarti remaja khususnya remaja putri yang aktif seksual berhak mencegah kehamilan yang tidak diinginkannya atau mengurangi masalah kesehatan reproduksi atas dirinya. Keluarga Berencana (KB) merupakan salah satu pelayanan kesehatan preventif yang paling dasar dan utama bagi wanita, meskipun tidak selalu diakui demikian. Oleh karena itu, perlu diidentifikasi pengetahuan dan sikap remaja terhadap pemakaian kontrasepsi (Musafaah. 2007).

\section{METODE PENELITIAN}

Penelitian ini dilaksanakan di Kampus Universitas Negeri Medan yang terletak dijalan Willem Iskandar Pasar V, Medan Estate, Sumatera Utara. Waktu penelitian dilaksanakan pada tanggal 25 November 2018 - 30 November 2018.

Jenis penelitian ini adalah penelitian deskriptif. Populasi penelitian ini adalah seluruh mahasiwa Universitas Negeri Medan. Sampel peneliti terdiri dari 70 Mahasiswa dengan usia yang beragam.

Teknik pengambilan data adalah suatu cara yang akan membuktikan suatu kebenaran data atau hasil yang akan di lakukan penelitian sehingga bisa di ambil sebuah kesimpulan (Sugiyono: 2014). Penelitian ini dilakukan dengan menggunakan desain penelitian deskriptif analitik dan pendekatan cross sectional. Sampel yang akan diambil menggunakan teknik accidental sampling dimana responden yang secara kebetulan ada dan dikenal peneliti serta dapat digunakan sebagai sampel. Alat atau instrument yang digunakan yaitu angket online dalam bentuk link. Angket ini dibuat dengan menggunakan google formulir. Skala pengukuran dalam penelitian ini menggunakan Skala Likert dengan tingkatan Setuju, Tidak Setuju, Sangat Setuju, Netral. Masing-masing pertanyaan memiliki bobotnya masing-masing. Dari angket online ini maka didapat tanggapan dari responden yang bersifat positif dan negative. Data yang digunakan yaitu data primer. Dalam penelitan ini teknik Analisis data meliputi analisis univariat yaitu dengan menggunakan distribusi frekuensi masingmasing variabel.

Penelitian terdiri dari tiga tahap yaitu tahap perencanaan, tahap pengumpulan data, dan tahap pengolahan data. Tahap perencanaan pada penelitian ini yaitu penentuan topik penelitian, subjek yang ingin diteliti, dan penyusunan alat pengumpulan data. Tahap pengumpulan data berupa penyebaran angket secara online melalui media sosial. Dan tahap pengolahan data berupa penyusunan hasil angket dalam bentuk tabel frekuensi dan mengklasifikasikan berdasarkan kategori yang telah ditetapkan. 


\section{HASIL DAN PEMBAHASAN}

\section{Karakteristik Responden}

Responden dari penelitian berkisar pada umur 17-23 tahun yaitu 5,7\% responden berumur 17 tahun, $5,7 \%$ responden berumur 18 tahun, $14,2 \%$ berumur 19 tahun, $37,14 \%$ responden berumur 20 tahun, $21,4 \%$ berumur 21 tahun, $5,7 \%$ berumur 22 tahun, dan $11,4 \%$ berumur 23 tahun. Sebanyak 91,4\% pendidikan responden yaitu lulusan SMA/SMK. Responden mendengar tentang kontrasepsi dari internet dan media sosial sebanyak $62,8 \%$, televisi sebanyak $20 \%$ responden, dan dari sumber lain sebanyak $12,8 \%$ responden.

\section{Pengetahuan Konstrasepsi}

Hasil penelitian menunjukkan bahwa 90\% responden mengetahui bahwa alat kontrasepsi dapat mencegah kehamilan. Sedangkan sebanyak $50 \%$ responden tidak mengetahui cara memakai berbagai alat kontrasepsi. Sebanyak $64,2 \%$ responden mengetahui bahwa alat kontrasepsi dapat mencegah penyakit menular. Dari hasil penelitian, dapat dilihat bahwa pengetahuan mahasiswa mengenai alat kontrasepsi masih dikatakan cukup baik. Hal ini dibuktikan dengan hampir sebagian besar responden mengetaui berbagai macam alat kontrasepsi dan fungsinya. Untuk sebaran distribusi mengenai pengetahuan responden terhadap kontrasepsi sebagai berikut :

Tabel 1. Pengetahuan Kontrasepsi

\begin{tabular}{|c|c|c|c|c|c|}
\hline No & Pernyataan & $\begin{array}{c}\text { Sangat } \\
\text { Tahu }\end{array}$ & Tahu & $\begin{array}{l}\text { Cukup } \\
\text { Tahu }\end{array}$ & $\begin{array}{l}\text { Tidak } \\
\text { Tahu }\end{array}$ \\
\hline 1 & Alat kontrasepsi dapat mencegah kehamilan & $90 \%$ & - & $10 \%$ & - \\
\hline 2 & $\begin{array}{l}\text { Mengetahui cara memakai berbagai macam } \\
\text { alat kontrasepsi }\end{array}$ & $1,4 \%$ & $12,8 \%$ & $32,8 \%$ & $50 \%$ \\
\hline 3 & $\begin{array}{l}\text { Mengetahui alat kontrasepsi dapat } \\
\text { mencegah penyakit menular }\end{array}$ & & $64,2 \%$ & - & $34,2 \%$ \\
\hline 4 & Pengetahuan mengenai sterilisasi wanita & - & $57,1 \%$ & - & $40 \%$ \\
\hline 5 & Pengetahuan mengenai sterilisasi pria & 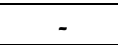 & & - & $61,4 \%$ \\
\hline 6 & Pengetahuan mengenai implant & - & $68,5 \%$ & - & $28,5 \%$ \\
\hline 7 & $\begin{array}{l}\text { Pengetahuan mengenai alat kontrasepsi } \\
\text { dalam rahim }\end{array}$ & - & $\%$ & - & $37,1 \%$ \\
\hline 8 & Pengetahuan mengenai KB Suntik & - & $90 \%$ & - & $10 \%$ \\
\hline
\end{tabular}

\section{Sikap terhadap Pemakaian Konstrasepsi}

Dari segi sikap responden terhadap pemakaian kontrasepsi sebagian besar menunjukkan respon yang negatif jika

dibandingkan dengan responden yang menunjukkan respon positif. Distribusi hasil dapat dilihat dalam tabel berikut :

Tabel 2. Sikap terhadap Pemakaian Kontrasepsi

\begin{tabular}{|c|c|c|c|c|c|}
\hline No & Pernyataan & $\begin{array}{l}\text { Sangat } \\
\text { Setuju }\end{array}$ & Setuju & Netral & $\begin{array}{l}\text { Tidak } \\
\text { Setuju }\end{array}$ \\
\hline 1 & $\begin{array}{l}\text { Remaja yang telah melakukan hubungan } \\
\text { seks dengan menggunakan alat kontrasepsi } \\
\text { agar tidak hamil }\end{array}$ & $\begin{array}{ll}- \\
-\end{array}$ & $12,8 \%$ & $24,2 \%$ & $60 \%$ \\
\hline 2 & $\begin{array}{l}\text { Remaja pria yang menggunakan kondom } \\
\text { untuk mencegah kehamilan }\end{array}$ & - & $22,8 \%$ & $27,1 \%$ & $47,1 \%$ \\
\hline
\end{tabular}

\section{KESIMPULAN}

Adapun kesimpulan yang di dapat dari penelitian ini, yaitu : (1) Sebagian besar remaja yang ada di Universitas Negeri Medan mengetahui bahwa alat kontrasepsi dapat mencegah kehamilan, (2) Sebagian 
besar remaja yang ada di Universitas Negeri Medan menunjukkan respon yang negatif jika dibandingkan dengan responden yang menunjukkan respon positif, (3) Sebagian besar responden tergolong mempunyai pengetahuan yang baik, (4) Sebagian besar mahasiswa di Universitas Negeri Medan memperoleh pengetahuan tentang kontrasepsi dari media sosial dan internet.

\section{DAFTAR PUSTAKA}

Aryanti, H. (2014). Faktor-faktor yang berhubungan dengan penggunaan kontrasepsi pada wanita kawin usia dini di Kecamatan Aikmel Kabupaten Lombok Timur. Tersedia di: http://www. pps. unud. ac. id/thesis/pdf thesi s/unud1007-437265649-hery\% 20aryanti, 20, 1292161023.

Lestari, N. M. S. D. (2013, December). Pengaruh dismenorea pada remaja. In Prosiding Seminar Nasional MIPA.

Muthiah, S., Kadarisman, Y., 2014. ESPON Pasangan Usia Subur (PUS) Terhadap
Program Keluarga Berencana (Kb) Di Desa Tanjung Belit Kecamatan Siak Kecil Kabupaten Bengkalis. Jurnal Online Mahasiswa FISIPOL Universitas Riau. Pekanbaru.

Musafaah. 2007. Pengetahuan dan Sikap Pemakaian Kontrasepsi pada Remaja Putri "Gaul" di Parkir Timur Senayan, Jakarta. Jurnal Kesehatan Masyarakat Nasional. 2(2) : 91 - 96.

Ramdhani, N. (2009). Sikap dan Beberapa Pendekatan dalam Memahaminya. dalam http:// neila. staff. ugm. ac. id/wordpress/wpcontent/uploads/2009/ 09/bab2-attitude. pdf, Akses, 1.

Suharyat, Y. (2009). Hubungan antara sikap, minat dan perilaku manusia. Jurnal Region, 1(3), 1-19.

Sugiyono. 2014. penelitian Kuantitatif kualitatif dan R \& D. Bandung: Alfabeta 